\title{
THE RESPONSE OF PIGEONPEA CULTIVARS TO SHORT DURATIONS OF WATERLOGGING
}

\author{
ABUHAY TAKELE' and C.R. MCDAVID \\ Department of Plant Science, the University of the \\ West Indies, St. Augustine, Trinidad \\ 'Present address- P.O. Box 100818, Addis Ababa, Ethiopia
}

(Received 3 May 1994; accepted 28 October 1994)

\begin{abstract}
The effects of short durations of waterlogging was investigated in three cultivars of pigeonpea (Cajanus cajan (L.) Millps); Tobago pea, Chag pearl and ICPL-19 grown in pots under greenhouse conditions at four waterlogging treatments (Control, $\mathbf{W L}_{1}, \mathrm{WL}_{2} \mathbf{W L}_{3}$ and $\mathrm{WL}_{4}$ ). Waterlogging treatments resulted in an increase in stomatal resistance, and reduced rates of transpiration and net photosynthesis in all the cultivars, but cultivar differences were not evident. With increasing number of cycles of waterlogging, there were increases in the stomatal resistance and reduction in rates of transpiration and net photosynthesis. Waterlogging also resulted in wilting, chlorosis, senescence and abscission of lower leaves after as little as two days of waterlogging. Leaf area development, dry weight accumulation per plant and partitioning were substantially reduced by waterlogging treatments, but the reduction in leaf area and dry weights were consistently greatest in ICPL-19 than Tobago pea and Chag pearl. The adverse effect of waterlogging observed in this study was associated to the greater degree of root damage in all the cultivars which in turn resulted in an increase in the resistance to water flow.
\end{abstract}

Key Words: Cajanus cajan, leaf area, net photosynthesis, stomatal resistance, transpiration rates

\section{RÉSUMÉ}

Les effets des imprégnations d'eau de courtes durées ont été analysés sur trois cultivars de pois d'Angole (Cajanus cajan (L.) Millps) comparés au pois de Tobago, au pois perlé et au ICPL-19 produits en pots dans des conditions sous serre suivant quatre traitements d'imprégnations (le témoin, $W L_{1}, W L_{2}, W L_{3}$ et $W L_{4}$ ). Les résultats des traitements d'imprégnations ont produit une augmentation de la résistance stomatale, un rythme réduit de transpiration et de nette photosynthèse dans tous les cultivars, mais les différences entre cultivars n'étaient pas évidantes. Avecl'augmentation du nombres de cycles d'imprégnation, il y avait une augmentation dans la résistance stomatale et une réduction dans le taux de transpiration et de photosynthèse nette. L'imprégnation a aussi produit des flétrissures, de la chlorose; de la sénescence et des abscissions des feuilles basses en moins de deux jours de traitements d'imprégnations. Les développements de la surface foliaire, les accumulations en poid sec par plante et la partition étaient substentiellement reduits par les traitements d'imprégnations, mais la réduction dans la surface foliaire et dans les poids sec étaient consistament plus élevés dans le ICPL-19 comparé au pois de tabago et au pois perlé. Les éffets défavorables de l'imprégnation observés dans cette étude étaient associés au plus grand degré de dommages racinaires dans tous les cultivars qui à leur tour ont eu pour résultat une augmentation de la résistance à l'écoulement de l'eau.

Mots Clés: Cajanus cajan, surface foliare, photosynthèse nette, résistance stomatale, taux de transpiration 


\section{INTRODUCTION}

Of the grain legumes, pigeonpea (Cajanus cajan (L.) Millps) is an important food crop and it is well adapted to tropical and subtropical climates of the world. Although the climatic conditions under which pigeonpea is cultivated are generally suitable, productivity of the crop is generally low through out the world. The low productivity is attributed to several major constraints, and important among them are soil moisture stress resulting from inadequate or excessive rainfall.

Waterlogging may occur as a result of high rainfall when evaporative demand is low (Meyer and Barrs, 1988) and unpredictable rainfall following irrigation (Hunt et al., 1981). The situation is further aggravated in clay soils which have characteristically poor internal drainage (Ariyanayagam and Griffith 1987; Meyer et al., 1987).

Shoot and root growth, dry matter accumulation and final grain yield of many agricultural crops including pigeonpea are adversely affected when the soil is temporarily or continuously waterlogged. This is attributed to the reduced availability of oxygen needed for root respiration and production of microbial toxins (Russell, 1977). Pegionpea is among the many grain legumes considered to be susceptible to short term waterlogging (Rachie and Roberts, 1974) and losses of up to 16 and $12 \%$ of dry matter and yield, respectively, have been reported when the duration of waterlogging was extended from 16 to $32 \mathrm{hr}$ (Hodgson et al., 1989).

It is well established that considerable variation in waterlogging tolerance exists between crop species (Brown et al., 1976; Hunter et al., 1980). The exposure of plants to waterlogging induces various physiological and morphological changes which might be related to differences in their tolerance to short term waterlogging. Relatively little is known, however, about the response of pigeonpea cultivars to waterlogging. The present study was conducted to investigate the effects of different durations of short term waterlogging on the physiology of growth and development of three cultivars of pigeonpea under greenhouse conditions.

\section{MATERIALS AND METHODS}

Pot experiments were carried out from December 1991 to mid-February, 1992 under greenhouse conditions using three cultivars of pigeonpea, i:e., Tobago pea, Chag pearl and ICPL-19.

Maximum and Minimum temperatures in the greenhouse during the period of the experiment ranged from $30-35^{\circ} \mathrm{C}$ and $20-23^{\circ} \mathrm{C}$, respectively. Average relative humidity was 60 percent and mid-day light intensity was $650 \mu \mathrm{E} \mathrm{m}^{-2} \mathrm{~S}^{-1}$.

Three seeds of each cultivar were sown in a pot of $15 \mathrm{~cm}$ diameter and $20 \mathrm{~cm}$ depth, containing sterilized air dried 1:2 sand/soil mixture. The pots had holes at the bottom for easy draining when necessary and were watered daily until the treatments began. Eight days after emergence, the plants were thinned to one per pot to give a uniform plant stand and, at 15 days after emergence, each of the three cultivars were subjected to the following waterlogging treatments:

a) Control = water applied daily as required throughout the study period.

b) $\mathrm{WL}_{1}=$ four cycles of waterlogging, each cycle consisting of 1 day waterlogging followed by 6 days drainage.

c) $\mathrm{WL}_{2}=$ four cycles of waterlogging, each cycle consisting of 2 days waterlogging followed by 5 days drainage.

d) $\mathrm{WL}_{3}=$ four cycles of waterlogging, each cycle consisting of 3 days waterlogging followed by 4 days drainage.

e) $\mathrm{WL}_{4}=$ four cycles of waterlogging, each cycle consisting of 4 days waterlogging followed by 3 days drainage.

The 15 treatment combinations were arranged factorially in a randomized complete block design with four replications. Waterlogging treatments were imposed by placing the planting pots into $20 \mathrm{~cm}$ diameter pots which were lined internally with polyethylene bags and filled with water. As a further precaution to prevent leakage, the draining holes of the outer pot were also sealed by an asphalt sealant. After the required period of waterlogging the inner pots were removed to allow drainage before repeating the cycle. The water in the pots was changed after each cycle.

During each cycle of waterlogging net photosynthesis $\left(\mathrm{P}_{\mathrm{a}}\right)$, transpiration, and stomatal 
resistance $(r)$ of the terminal leaflet of the top most fully expanded leaves were measured using an infrared gas analyser (LCA-2 portable photosynthesis system, ADC, England). Visual assessment of chlorosis was made using 0-5 scale at each cycle of waterlogging. Leaf area was measured using an automatic area meter (Model AAM-5, Hayashi Denko Co. Ltd., Tokyo). At 65 days after planting, when the plants were still at the vegetative stage, dry matter accumulation and distribution was determined by separating the harvested plants into leaf, stem and roots. The root system was carefully washed to remove soil and other debries, if any, and the plant parts dried in a ventilated oven at $80^{\circ} \mathrm{C}$ for $72 \mathrm{hr}$ and weighed.

\section{RESULTS}

Stomatal resistance $\left(r_{s}\right)$, transpiration rates and net photosynthesis $\left(P_{n}\right)$. Mean data for $r_{s}$, transpiration rates, $P_{n}$, visual symptoms (chlorotic score 0-5) and leaf area development as effected by the waterlogging treatments are shown in Table 1.

Waterlogging significantly $(\mathrm{P}<0.01)$ increased $r_{s}$ in all the cultivars, the increase ranging from 2 to 6 folds in the $\mathrm{WL}_{2} \mathrm{WL}_{3}$ and $\mathrm{WL}_{4}$ treatments, suggesting that stomatal closure was induced by the waterlogging. The mean stomatal resistance values recorded were $3.6,5.9,13.4,19.9$ and 15.4 $\mathrm{S} \mathrm{cm}^{-1}$ for the control, $\mathrm{WL}_{1}, \mathrm{WL}_{2}, \mathrm{WL}_{3}$ and $\mathrm{WL}_{4}$, respectively, with no significant difference between cultivars. Increasing the number of waterlogging cycles also resulted in a significant increase in $r_{s}$, with the mean $r_{s}$ after the $1^{\text {st }}, 2^{\text {nd }}$ and $3^{\text {rd }}$ cycles being $3.9,10.8$ and $20.3 \mathrm{~S} \mathrm{~cm}^{-1}$, respectively (Table 2 ).

Transpiration rates and $P_{n}$ were significantly reduced with increasing duration of waterlogging treatments. Maximum reduction of about $61 \%$ in transpiration rates occurred in $\mathrm{WL}_{3}$ and $\mathrm{WL}_{4}$ treatments and the lowest value of $P_{n}\left(3.6 \mu \mathrm{M} \mathrm{m}^{\text {. }}\right.$ ${ }^{2} \mathrm{~S}^{-1}$ ) occurred in the $\mathrm{WL}_{3}$ treatment, and was about $72 \%$ lower than that of the control.

Increasing the number of cycles of waterlogging also significantly $(\mathrm{P}<0.01)$ reduced both transpiration rates and $P_{n}$ (Table 2). The mean transpiration rates after the $2^{\text {nd }}$ and $3^{\text {rd }}$ cycles of waterlogging declined by 54 and $80 \%$ and those of $\mathrm{P}_{n}$ by 18 and $76 \%$, respectively.

Visual symptoms. Waterlogging treatments adversely affected all the cultivars tested. The major visual responses to extended periods of waterlogging were chlorosis and senescence of the lower leaves followed by abscission and wilting. Table 1 gives visual estimates of the degree of chlorosis in response to waterlogging. Chlorosis and wilting were induced after as little as two days of the commencement of the treatment and became more severe with increasing duration of waterlogging in all the cultivars. The degree of chlorosis was similar in Tobago pea and Chag pearl cultivars, ranging from slight to moderate in all the treatments, but was more severe in ICPL19. Senescence and abscission of the lower leaves

TABLE 1. The effect of four levels of waterlogging on mean stomatal resistance, transpiration rate, net photosynthesis, chlorosis and leaf area in three cultivars of pigeonpea

\begin{tabular}{lccccc}
\hline Treatment & $\begin{array}{c}\left(\mathrm{r}_{\mathrm{s}}\right) \\
(\mathrm{sm})\end{array}$ & $\begin{array}{c}\text { Transpiration } \\
\left(\mathrm{m} \mathrm{Mm}^{-1} \mathrm{~S}^{-1}\right)\end{array}$ & $\begin{array}{c}\left(\mathrm{P}_{\mathrm{n}}\right) \\
\left(\mu \mathrm{Mm}^{-2} \mathrm{~S}^{-1}\right)\end{array}$ & $\begin{array}{c}\text { Chlorosis } \\
(0-5)\end{array}$ & $\begin{array}{r}\text { Leaf area } \\
\left(\mathrm{cm}^{2} \text { plant }^{-1}\right)\end{array}$ \\
\hline Control & 3.6 & 3.5 & 12.6 & 0 & 1033.5 \\
$W_{1}$ & 5.9 & $2.6(25)$ & $9.2(27)$ & 1.2 & $344.5(67)$ \\
$W_{2}$ & 13.4 & $1.9(42)$ & $5.4(57)$ & 1.7 & $171.3(83)$ \\
$W_{2}$ & 19.9 & $1.3(61)$ & $3.6(71)$ & 2.6 & $121.6(88)$ \\
$W_{3}$ & 15.4 & $1.4(61)$ & $3.8(70)$ & 2.3 & $128.0(88)$ \\
\hline LSD $(0.01)$ & 5.13 & 0.43 & 1.86 & 0.92 & 94.3 \\
C.V $(\%)$ & 18.6 & 21.20 & 20.40 & 12.50 & 31.80 \\
\hline
\end{tabular}

Numbers in brackets are percentage decrease in transpiration rates, $P_{n}$ and leaf area development in the waterlogged treatments as compared to the control.

$W L_{1}-W L_{4}$ indicate one to four days of waterlogging treatments, respectively. 
TABLE 2. The effect of three cycles of wateriogging on the mean stomatal resistance, transpiration and net photosynthesis of three cultivars of pigeonpea

\begin{tabular}{lccc}
\hline $\begin{array}{l}\text { Number of } \\
\text { cycles }\end{array}$ & $\begin{array}{c}\mathrm{rs} \\
\left(\mathrm{S} \mathrm{cm}^{-1}\right)\end{array}$ & $\begin{array}{c}\mathrm{P}_{\mathrm{n}} \\
\left(\mu \mathrm{M}_{\mathrm{m}} \mathrm{s}^{-1}\right)\end{array}$ & $\begin{array}{c}\text { Transpiration } \\
\left(\mathrm{m} \mathrm{M}^{-2} \mathrm{~s}^{-1}\right)\end{array}$ \\
\hline 1 & 3.9 & 10.06 & 3.85 \\
2 & 10.8 & $8.25(18)$ & $1.76(54)$ \\
3 & 20.3 & $2.43(76)$ & $0.78(80)$ \\
\hline LSD(0.01) & 3.97 & 1.44 & 0.34 \\
C.V.(\%) & 18.60 & 20.40 & 21.20 \\
\hline
\end{tabular}

Numbers in brackets are percentage decrease in transpiration rates and net photosynthesis relative to the value of the $1^{\text {st }}$ cycle.

was, however, more pronounced in Tobago pea and ICPL-19 relative to Chag pearl.

One of the common symptoms of waterlogging was wilting of the leaves which began during the $2^{\text {nd }}$ cycle and became severe during the $3^{\text {rd }}$ and $4^{\text {th }}$ cycles. The effect was so severe in ICPL-19 that some plants of this cultivar died during the $\mathrm{WL}_{3}$ and $\mathrm{WL}_{4}$ treatments.

Leaf area development. Waterlogging for as little as one day significantly $(\mathrm{P}<0.01)$ reduced leaf area development, with the reduction ranging from 67 to $88 \%$ for the $\mathrm{WL}_{1}$ and $\mathrm{WL}_{4}$ treatments, respectively (Table 1 ). There was also a significant $(\mathrm{P}<0.05)$ difference in mean leaf area development among the cultivars in response to waterlogging, with Chag pearl having the highest and ICPL-19 the lowest leaf areas (Table 3).

Dry matter accumulation. Among the cultivars, mean leaf dry weight was significantly lower in ICPL-19 and Tobago pea than Chag pearl (Table $3)$. Mean leaf dry weights for the three cultivars

TABLE 3. Mean leaf area. leaf, stem and total dry weights of three cultivars of pigeonpea as influenced by four levels of waterlogging

\begin{tabular}{lcccc}
\hline Cultivar & $\begin{array}{c}\text { Leaf } \\
\text { area } \\
\text { (cm }\end{array}$ plant $\left.^{-1}\right)$ & \multicolumn{3}{c}{ Dry weight $\left(\mathrm{g} \mathrm{plant}^{-1}\right)$} \\
\cline { 3 - 6 } & Leaf & Stem & Total \\
\hline Tobago pea & 341.1 & 1.52 & 1.44 & 3.8 \\
Chag pearl & 439.6 & 1.96 & 1.77 & 4.3 \\
ICPL-19 & 298.7 & 1.28 & 0.97 & 2.6 \\
\hline LSD $(0.05)$ & 73.02 & 0.30 & 0.14 & 0.78 \\
C.V $(\%)$ & 31.80 & 30.40 & 28.30 & 34.10 \\
\hline
\end{tabular}

were $1.28,1.52$ and $1.96 \mathrm{~g} \mathrm{plant}^{-1}$, respectively. Mean stem dry weight also differed significantly $(\mathrm{P}<0.05)$ between cultivars with the highest stem dry weight ( $\left.1.8 \mathrm{~g} \mathrm{plant}^{-1}\right)$ occuring in Chag pearl and the lowest $\left(0.97 \mathrm{~g} \mathrm{plant}^{-1}\right)$ in ICPL-19.

The mean values of leaf, stem and total dry weights for the control, $\mathrm{WL}_{1}, \mathrm{WL}_{2}, \mathrm{WL}_{3}$ and $\mathrm{WL}_{4}$ treatements are presented in Table 4. All of these parameters were consistently reduced with increasing durations of waterlogging. The reduction in leaf dry weight ranged from 68 to $88 \%$ in $\mathrm{WL}_{1}$ and $\mathrm{WL}_{4}$, respectively, and the corresponding reduction in stem dry weight ranged from 64 to $78 \%$.

Differences in mean root dry weight between the treatments were highly significant $(\mathrm{P}<0.01)$ and root dry weight declined by $81,91,92$ and $93 \%$ for the $\mathrm{WL}_{1}, \mathrm{WL}_{2}, \mathrm{WL}_{3}$ and $\mathrm{WL}_{4}$ treatments respectively, relative to the control (Table 4). Observation of the root system at harvest time indicated that several roots in all the cultivars in the $\mathrm{WL}_{3}$ and $\mathrm{WL}_{4}$ treatments apppeared to be dead and in most cases were blackened. This suggests that roots of these cultivars were extremely sensitive to short-term waterlogging in excess of two days.

The interaction between cultivars and treatments was significant $(\mathrm{P}<0.05)$ for root dry weight (Table 5 ) indicating that differences between cultivars exist in the extent of root growth suppression as a result of the treatments. In Tobago pea there was

TABLE 4. The effect of four levels of waterlogging on leaf, stem and total dry weights in three cultivars of pigeonpea.

\begin{tabular}{llll}
\hline Treatment & $\begin{array}{c}\text { Leaf dry } \\
\text { weight } \\
\text { (g plant }\end{array}$ & $\begin{array}{c}\text { Stem dry } \\
\text { weight } \\
\text { (g plant }{ }^{1} \text { ) }\end{array}$ & $\begin{array}{c}\text { Total dry } \\
\text { weight } \\
\text { (g plant }\end{array}$ \\
\hline Control & 4.55 & 3.15 & 9.9 \\
$W_{1}$ & $1.48(68)$ & $1.15(64)$ & $2.9(71)$ \\
$W_{2}$ & $0.73(84)$ & $1.01(68)$ & $1.95(80)$ \\
$W_{2}$ & $0.63(86)$ & $0.97(69)$ & $1.8(82)$ \\
$W_{3}$ & $0.56(88)$ & $0.69(78)$ & $1.4(86)$ \\
\hline LSD $(0.01)$ & 0.40 & 0.68 & 1.01 \\
C.V $(\%)$ & 30.40 & 28.30 & 34.10 \\
\hline
\end{tabular}

Numbers in parenthesis are percentage decrease in leaf, stem and total dry weight in the waterlogged treatments as compared to the controt.

$C$ and $W L_{1}=W L_{4}$ indicate control and one to four days of waterlogging treatments, respectively. 
a consistent reduction in root dry weight with increase in the duration of waterlogging from $W_{1}$ to $\mathrm{WL}_{3}$, but in the $\mathrm{WL}_{4}$ treatment root dry weight tended to increase relative to the $\mathrm{WL}_{3}$ treatment. In Chag pearl there was a consistent decline in root dry weight with increase in the duration of waterlogging treatments, while the response of ICPL-19 did not follow a definite pattern.

The effect of waterlogging treatments on total dry weight was also strongly significant and average reduction of $71,80,82$ and $86 \%$ occurred in the $\mathrm{WL}_{1}, \mathrm{WL}_{2}, \mathrm{WL}_{3}$ and $\mathrm{WL}_{4}$ treatments, respectively, as compared to the control (Table 4). The cultivars also exhibited significant $(\mathrm{P}<0.05)$ differences as a result of the waterlogging treatments, and the reduction in total dry weight was relatively less in Chag pearl than in the other cultivars. The reduction in total dry weight was attributable to the loss of leaf dry weight as a result of senescence and abscission, and loss of stem and root dry weights.

Dry matter partitioning. The leaf weight ratio (LWR) was significantly $(\mathrm{P}<0.05)$ lower in the $\mathrm{WL}_{2}, \mathrm{WL}_{3}$ and $\mathrm{WL}_{4}$ treatments relative to the control and $W_{1}$ treatments (Table 6). In contrast, mean stem weight ratio (SWR) was significantly higher in the $\mathrm{WL}_{2}$ and $\mathrm{WL}_{4}$ treatments than the control. SWR for the cultivars was significantly $(P<0.05)$ different as a result of the waterlogging treatments (Table 7). Mean SWR was significantly lower for ICPL-19 (0.29) than for Chag pearl $(0.39)$ and Tobago pea (0.43). The higher values of SWR in Tobago pea correspond with the higher leaf dry weight loss in this cultivar. However, in the case of ICPL-19, the results suggest that the greater leaf dry weight loss was accompanied by a correspondingly large reduction in stem dry

TABLE5. The effect of four levels of waterlogging on the root dry weight (g plant ${ }^{-1}$ ) in three cultivars of pigeonpea

\begin{tabular}{lccccc}
\hline Cultivar & Control & $W L_{1}$ & $W L_{2}$ & $W L_{3}$ & $W L_{4}$ \\
\hline Tobago & 3.33 & 0.59 & 0.25 & 0.18 & 0.23 \\
Chag pear & 2.29 & 0.62 & 0.38 & 0.22 & 0.15 \\
ICPL-19 & 2.01 & 0.23 & 0.10 & 0.23 & 0.14 \\
\hline LSD (0.05) & \multicolumn{5}{c}{0.48} \\
C.V. (\%) & \multicolumn{5}{c}{22.8} \\
\hline
\end{tabular}

weight indicating that this cultivar is extremely sensitive to short-term waterlogging as compared to the other two cultivars.

TABLE 6. The effect of four levels of waterlogging on mean Leaf Weight Ratio, Stem Weight Ratio and Root: Shoot Ratio in three cultivars of pigeonpea

\begin{tabular}{lccc}
\hline Treatment & $\begin{array}{c}\text { Leaf weight } \\
\text { ratio }\end{array}$ & $\begin{array}{c}\text { Stem weight } \\
\text { ratio }\end{array}$ & $\begin{array}{c}\text { Root:shoot } \\
\text { ratlo }\end{array}$ \\
\hline Control & 0.47 & 0.28 & 0.34 \\
$W L_{1}$ & 0.53 & 0.31 & 0.39 \\
$W L_{2}$ & 0.36 & 0.43 & 0.15 \\
$W_{3}$ & 0.32 & 0.39 & 0.12 \\
$W_{4}$ & 0.36 & 0.44 & 0.14 \\
\hline LSD & $0.11^{*}$ & $0.12^{*}$ & $0.06^{* * *}$ \\
C.V.(\%) & 32.10 & 30.30 & 34.10 \\
\hline
\end{tabular}

$* P<0.05$

**** $=P<0.01$

$C$ and $W L_{1}-W L_{4}$ indicate control and one to four days of waterlogging treatments, respectively.

TABLE 7. Mean stem weight ratio and root: shoot ratio of three cultivars of pigeonpea as influenced by four levels of waterlogging

\begin{tabular}{lcc}
\hline Cultivar & stem wegint ratio & root: shoot ratio \\
\hline Tobago pea & 0.43 & 0.24 \\
Chag peart & 0.39 & 0.17 \\
ICPL-19 & 0.29 & 0.16 \\
& & \\
\hline LSD (0.05) & 0.08 & 0.04 \\
C.V.(\%) & 30.30 & 34.10 \\
\hline
\end{tabular}

The mean values for root:shoot ratio (RSR) showed that waterlogging treatments significantly $(\mathrm{P}<0.01)$ reduced $\mathrm{RSR}$ with the reduction being more severe in the $\mathrm{WL}_{3}$ and $\mathrm{WL}_{4}$ treatments. On the average RSR was reduced by $44,56,62$ and $59 \%$ in the $\mathrm{WL}_{1}, \mathrm{WL}_{2}, \mathrm{WL}_{3}$ and $\mathrm{WL}_{4}$ treatments, respectively, relative to the control. The mean RSR of Tobago pea was markedly higher than that of both Chag pearl and ICPL-19 (Table 7).

\section{DISCUSSION}

Pigeonpea was found to be extremely sensitive to waterlogging in agreement with the previous reports by Rachie and Roberts (1974). Waterlogging resulted in wilting, chlorosis and senescence and abscission of the lower leaves after as little as two days in all the cultivars. 
Symptoms of chlorosis is believed to be associated with reduced uptake of nitrogen and the consequent remobilization of nutrients from the lower to the young upper leaves (Drew and Sisworo, 1979). This has been reported in waterlogged sensitive species such as peas (Jackson, 1979; Belford et. $a l ., 1980)$ and barley (Drew and Sisworo, 1979).

Interesting among the responses observed was the rapid wilting of all cultivars, the effect being more pronounced in ICPL-19 than in the other cultivars. Although leaf water potential was not measured in this study, data for $r_{s}$ (Table 1) and wilting of the plants suggests that plants in the waterlogging treatments experienced transient water stress. This may have resulted from increased resistance to water flow in the roots (Parson and Kramer, 1974), which has been demonstrated in many crop species such as cowpea and maize (Wien etal., 1979), Phaseolus species (El-Beltagy and Hall, 1974) and tomato (Kramer and Jackson, 1954). The rapid increase in $r$, and subsequent reduction in transpiration and $\overrightarrow{\mathrm{P}}_{\mathrm{n}}$ of waterlogged plants as a result of stomatal closure, may be an adaptive response to water stress caused either by water deficit or excesses. Lopez (1986) reported that the drought resistance of pigeonpea involves osmoregulation and maintenance of turgor at low leaf water potential. The rapid wilting and stomatal closure in response to waterlogging found in this study, however, suggests that pigeonpea loses its osmoregulatory ability under short-term waterlogging. This may be a result of leaf tissue damage and increased leakiness of the cell membranes resulting in loss of osmotic control in response to waterlogging which has been reported by Jackson and Kowalewska (1983). They also suggested that phosphorus toxicity may be a possible cause of wilting as in the waterlogging of sensitive pea (Pisum sativum) plants.

Waterlogging resulted in an increase in $\mathrm{r}_{3}$ over that of the control plants. This result is in agreement with the findings of Wien et al. (1979), Bradford and Hsiao (1980), Sojka (1985), and Van Wadman and van Andel (1985) who reported an increase in $r_{s}$ accompanied by a decline in transpiration rates and $P_{n}$. An increase in $r_{s}$ under waterlogged conditions may be a direct response to changes in hormone concentration and increases in ABA content (Van Wadman and van Andel, 1985) as well as decreased cytokinin and gibberellin supply from the anaerobic roots (Jackson and Campbell, 1979). Reduced K uptake and/or K concentration in guard cells (Drew and Sisworo, 1979; Sojka, 1985) may also stimulate an increase in $r_{s}$.

The growth of lateral branches, and average leaf sizes was greatly reduced in waterlogged plants. These two factors, together with the loss of turgor, premature senescence and abscission of older leaves, were the major causes of reduced leaf area in all the cultivars. These in turn severely reduced dry matter production and shoot and root growth in all the cultivars, with ICPL-19 consistently producing less total dry weight than Tobago pea and Chag pearl.

Root dry weight of all cultivars was particularly sensitive to waterlogging and a single day of waterlogging resulted in a subsequent average reduction in root dry weight of $81 \%$. This damage to the roots would be expected to increase root resistance to water flow through roots (Kramer and Jackson, 1954), decrease absorption of nutrients (Drew and Sisworo, 1979; Throught and Drew, 1980), and to change hormonal balance (Jackson and Campbell, 1979). In grain legumes, waterlogging also has a direct effect on nodule activity (Minchin et al., 1978; Wein et al., 1979) which adversely affects shoot growth.

The results of this study confirm that pigeonpea cultivars tested are extremely sensitive and are unable to tolerate waterlogging in excess of one day.

\section{ACKNOWLEDGEMENTS}

This paper was part of an M. Phil. research thesis submitted to The University of The West Indies, St. Augustine, Trinidad, W.I. by the first author. The work was financed by FAO/UNDP of the United Nations. We thank scientists and staff of the University for their support and FAO/UNDP for the sponsorship.

\section{REFERENCES}

Ariyanayagam, R.P. and Griffith, S.M. 1987. Soil and climate environment in the Caribbean region, yield reduction in pigeonpea due to drought, salinity, acidity and alkalinity. In: Adaptation of Chickpea and Pigeonpea to Biotic Stresses, Proceedings of the Consultants 
Workshop, 19-20 Dec. 1984, pp.149-158. International Crop Research Institute for the semi-Arid Tropics (ICRISAT), Patancheru, A.P. India.

Belford, R.K., Cannell, R.Q., Thomson, R.J. and Dennis, C.W. 1980. Effects of waterlogging at different stages of development on the growth and yield of peas (Pisium sativum L.). Journal of the Science of Food and Agriculture 31: 857-869.

Bradford, K.J. and Hsiao, T.C. 1982. Stomatal behaviour and water relations of waterlogged tomato plants. Plant Physiology 70: 15081518.

Brown, K.W., Jordan, W.R. and Thomas, J.C. 1976. Water stress induced alteration in the stomatal response to leaf water potential. Physiologia Plantarum 37: 1-5.

Drew, M.C. and Sisworo, E.J. 1979. The development of waterlogging damage in young barley plants in relation to plant nutrient status. New Phytologist 82: 301-314.

El-Beltagy, A.S. and Hall, M.A. 1974. Effect of water stress upon endogenous ethylene levels in Vicia faba. New Phytologist 73: 47-60.

Hodgson, A.S., Holland, J.F. and Rayner, P. 1989. Effects of field slope and duration of furrow irrigation on growth and yield of six grain legumes on a waterlog prone vertisol. Field Crops Research 22: 165-180.

Hunt, P.G., Campbell, R.B., Sojka, R.E. and Parsons, J.E. 1981. Flooding induced soil and plant ethylene accumulation and water status response of field grown tobacco. Plant and Soil 59: 427-439.

Hunter, M.N., DeJabrun, P.L.M. and Byth, D.E. 1980. Response of nine soybean lines to soil moisture conditions close to saturation. Australian Journal of Experimental Agriculture and Animal Husbandry 20:339. 345.

Jackson, M.B. 1979. Rapid injury to peas by waterlogging. Journal of the Science of Food and Agriculture 30: 143-152.

Jackson, M.B. and Campbell, D.J. 1976. Waterlogging and petiole epinasty in tomato, the role of ethylene and oxygen. New Phytologist 76: 21-29.

Jackson, M.B. and Campbell, D.J. 1979. Effect of benzyladenine and gibberellic acid on the responses of tomato plants to anaerobic root environments and to ethylene. New Phytologist 82: 331-340.

Jackson, M.B. and Kowalewska, A.K.B. 1983. Positive and negative messages from roots induced foliardesiccation and stomatal closure in flooded pea plants. Joumal of Experimental Botany 34: 493-506.

Kramer, P.J. and Jackson, W.T. 1954. Causes of injury to flooded tobacco plants. Plant Physiology 29: 241-245.

Lopez, F. 1986. Drought Resistance Studies in Pigeonpea. Ph.D. Thesis, The University of the West Indies, St. Augustine Campus, Trinidad, West Indies.

Meyer, W.S. and Barrs, H.D. 1988. Responses of wheat to single, short-term waterlogging during and after stem elongation. Australian Journal of Agricultural Sciences 39: 11-20.

Meyer, W.S., Reicosky, D.C., Barrs, H.D. and Smith, R.C.G. 1987. Physiological responses of cotton to a single waterlogging at high and low N-levels. Plant and Soil 102: 161-170.

Minchin, F.R., Summerfie1d, R.J., Eaglesham, A.R.J. and Stewart, K.A. 1978. Effects of short term waterlogging on growth and yield of cowpea (Vigna unguiculata). Journal of Agricultural Science 90: 355-366.

Parson, K.D., and Kramer, P.J. 1974. Diurinal cycling in root resistance to water movement. Physiologia Plantarum 30: 19-23.

Rachie, K.D., and Roberts, L.M. 1974. Grain legumes of the lowland tropics. Advances in Agronomy 26: 1-132.

Russell, R.S. 1977. Effects of anaerobic soil conditions. In: Plant Root Systems, Their Function and Interaction With the Soil. pp. 193-219. McGraw Hill, London.

Sojka, R.E. 1985. Soil oxygen effects on two determinate soybean isolines. Soil Science 140: 333-343.

Throught, M.C.T. and Drew, M.C. 1980. The development of waterlogging damage in wheat seedlings (Triticum aestivum L). I. Shoot and root growth in relation to changes in the concentration of dissolved gases and solutes in the soil solution. Plant and Soil 54: 77-94.

Van Wadman, S.H. and van Andel, O.M. 1985. The role of ethylene during flooding of 
Phaseolus vulgaris. Physiologia Plantarum 66: 257-264.

Wien, C., Lal, R. and Pulver, E. 1979. Effects of transient flooding on growth and yield of some tropical crops. In: Soil Physical Properties and Crop Production in the Tropics. Lal, R. and Greenland, D.J. (Eds.), pp. 235-245. John Wiley and Sons, New York. 